decrease in PsA patients, and also to the arousal of central heart rhythm regulation mechanisms combined disorders.

Disclosure of Interest: None declared

DOI: 10.1136/annrheumdis-2018-eular.1611

\section{AB0924 \\ EFFICACY OF SUBCUTANEOUS USTEKINUMAB THERAPY IN PATIENTS WITH PSORIATIC ARTHRITIS: A SINGLE CENTRE-STUDY}

I. Añón Oñate, I. Notario Ferreira, L. Pérez Albaladejo, M. Á. Ferrer González, M. Ramírez de la Torre, S. Quirosa Flores, A. García Sánchez, M.C. Ramírez Barberena, J.M. Andreu Ubero, R. Cáliz Cáliz. Rheumatology, Hospital

Universitario Virgen de las Nieves de Granada, Granada, Spain

Background: Ustekinumab is a monoclonal antibody that inhibits IL-12 and 23 that has demonstrated efficacy and safety for the treatment of patients with psoriatic arthritis, plaque psoriasis and Crohn's disease.

Objectives: To evaluate the efficacy of subcutaneous Ustekinumab (USTE) in patients with psoriatic arthritis in a real-world clinical setting in Spain.

Methods: Descriptive, prospective, longitudinal and open study of 66 patients diagnosed with psoriatic arthritis: 63 patients received subcutaneous USTE $45 \mathrm{mg}$ and 3 patients received USTE $90 \mathrm{mg}$ every 12 weeks, both groups received a first dose of induction according to technical specifications. The following variables were collected: age, sex, years of evolution, previous treatment with Synthetic Disease Modifying Anti-Rheumatic Drugs (DMARDs) and/or biologic DMARD, counting of painful and swollen joints, determination of C-reactive protein, presence of dactylitis, onychopathy and cutaneous psoriasis. Clinical efficacy was evaluated by EULAR response criteria and Disease Activity Score (DAS28) according to low activity criteria (DAS28 >2.6-3.2) and remission clinical (DAS28 <2.6) at 6 and 12 months of treatment. Efficacy was compared between 2 subgroups; one group was: patients with USTE monotherapy vs USTE in combination therapy with DMARDs and the other group was: naïve patients vs patients who received previous treatment with biologic DMARD. Enthesis affectation was evaluated with the MASES index.

Results: 66 patients were included, $51.5 \%$ were female. The mean age was 47.2 \pm 11.3 years and the mean disease duration was $6 \pm 7.76$ years. USTE was prescribed in $44 \%$ as a first line therapy and was administered in combination with DMARDs in $51.5 \%$ of the patients (mostly, methotrexate). In our cohort, $74.2 \%$ of patients had exclusively peripheral involvement, $10.6 \%$ had axial involvement and $15.2 \%$ had mixed involvement. $21 \%$ of our patients had dactylitis and $36 \%$ enthesitis, as well as cutaneous psoriasis (74\%) and onicopathy (42\%). At 6 and 12 months of treatment, we observed a statistically significant decrease in the count of painful and swollen joints, in the DAS28 index and in the MASES index. DAS28 low disease activity rates were $38 \%$ at 6 months and $21 \%$ at 12 months of treatment. DAS28 remission rates were $21 \%$ and $14 \%$ at 6 and 12 months respectively. When comparing efficacy by subgroups, we observed higher EULAR response rates in patients with USTE in combination therapy with DMARDs (figure 1) and biologic DMARD-naïve patients (Figure 2) at 6 and 12 months of treatment.
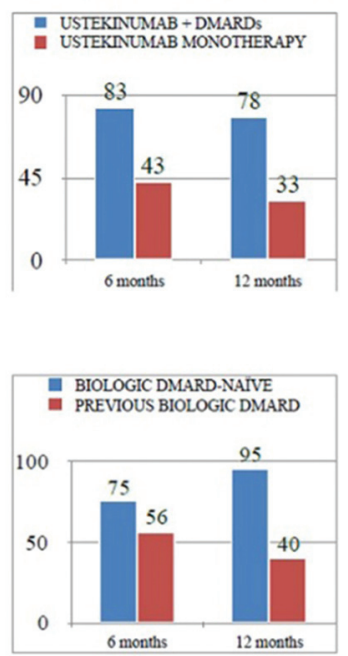

$\begin{array}{lll}\begin{array}{l}\text { Not } \\ \text { fulfilled }\end{array} & 101 & 49,03 \%\end{array}$

fulfilled

MDA

$90 \mathrm{mg}$ may improve the response to treatment in some patients, but we would need a greater number of studies in clinical practice.

Disclosure of Interest: None declared

DOI: 10.1136/annrheumdis-2018-eular.3252

\section{AB0925 1 COMPARISON OF PSORIATIC ARTHRITIS THERAPEUTIC TARGETS - PSA-MDA AND DAPSA REMISSION/LOW DISEASE ACTIVITY IN PATIENTS TREATED IN THE INSTITUTE OF RHEUMATOLOGY PRAGUE}

J. Stolfa ${ }^{1,2}$, L. Sedova ${ }^{1,2}$, Z. Mares ${ }^{1} .{ }^{1}$ Institute of Rheumatology; ${ }^{2}$ Clinic of Rheumatology, First Medical Faculty, Charles University, Prague, Czech Republic

Background: According to the Czech Society of Rheumatology guidelines for therapy and monitoring of psoriatic arthritis from 2016 $\left({ }^{1}\right.$ which are based on the EULAR recommendations 2015(2) the target of the therapy is to attain either minimal disease activity (MDA)(3) or remission/low disease activity according to DAPSA(4). In fact, the majority of our patients have only mild skin disease and that's why DAPSA, which is more feasible to use could be sufficient as a target of therapy, even though these two indices assess the disease from different points of view (MDA being more comprehensive, including also entheses, skin and function and DAPSA only joint disease).

Objectives: To compare the ability of these two indices in the evaluation of the response to treatment.

Methods: We compared both indices from 206 visits in 32 patients with PsA from our database of 247 patients. At first we took the patients who complied with MDA criteria and looked at what percentage of them were in remission/low disease activity, moderate, or high activity respectively at the same time. Then, we took the paients, who did not comply with MDA criteria and again looked at the level of activity according to DAPSA.

Results: In the group of patients who fulfilled the MDA criteria (5/7), 99,5\% were also in the state of remission or low disease activity according to DAPSA. In only 1 case the activity was assessed as moderate and no patient was in high disease activity state. In the group of patients who did not comply with MDA criteria, $42,6 \%$ of pats. were in mild disease activity state and only $57,4 \%$ of patients were in moderate, or high activity according to DAPSA - Tab. 1

Abstract AB0925 - Table 1

Pats. $206 \quad 100 \%$ Total:

total.

(n):

Fulfilled $105 \quad 50,97 \%$

MDA

\begin{tabular}{|c|c|c|c|c|}
\hline $\begin{array}{l}\text { Of total in } \\
\text { remission } \\
\text { (DAPSA): }\end{array}$ & 40 & $38,10 \%$ & $99,05 \%$ & $p<0,01$ \\
\hline $\begin{array}{l}\text { fotal in mild } \\
\text { aktivity } \\
\text { (DAPSA): }\end{array}$ & 64 & $60,95 \%$ & & \\
\hline $\begin{array}{l}\text { Of total in } \\
\text { moderate } \\
\text { aktivity } \\
\text { (DAPSA): }\end{array}$ & 1 & $0,95 \%$ & & \\
\hline $\begin{array}{l}\text { Of total in } \\
\text { high aktivity } \\
\text { (DAPSA): }\end{array}$ & 0 & $0,00 \%$ & & \\
\hline $\begin{array}{l}\text { Of total in } \\
\text { remission } \\
\text { (DAPSA): }\end{array}$ & 0 & $0,00 \%$ & & \\
\hline $\begin{array}{l}\text { total in mild } \\
\text { aktivity } \\
\text { (DAPSA): }\end{array}$ & 43 & $42,57 \%$ & & \\
\hline $\begin{array}{l}\text { Of total in } \\
\text { moderate } \\
\text { aktivity } \\
\text { (DAPSA): }\end{array}$ & 50 & $49,50 \%$ & $57,43 \%$ & $\mathrm{p}<0,05$ \\
\hline $\begin{array}{l}\text { Of total in } \\
\text { high aktivity } \\
\text { (DAPSA): }\end{array}$ & 8 & $7,92 \%$ & & \\
\hline
\end{tabular}

Conclusions: Ustekinumab is effective for the treatment of psoriatic arthritis and constitutes an alternative to treatment with anti-TNF $\alpha$. The dose of Ustekinumab 


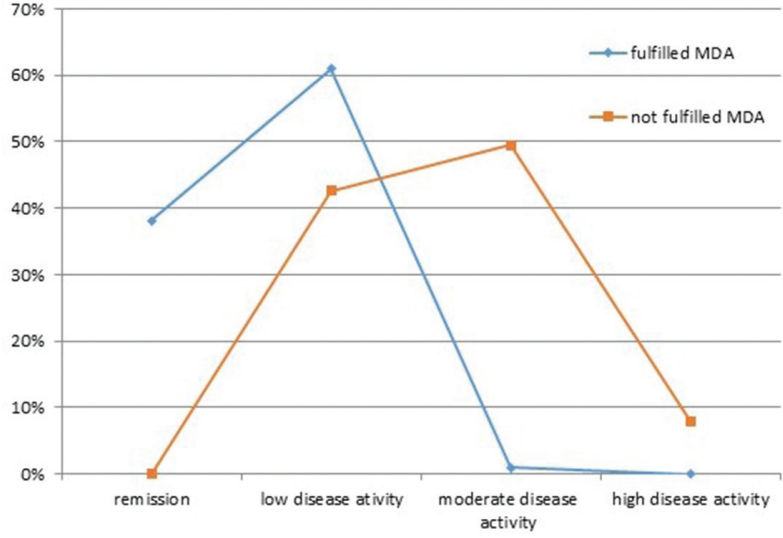

Abstract AB0925 - Figure 1

Conclusions: DAPSA correlates well with MDA in patients with mild skin disease and can be used in these patients instead of MDA. In patients who fail to respond to therapy according to MDA there can be a substantial proportion of patients with mild joint disease, due to more severe skin disease and/or presence of enthesitidies, which are nevertheless vaguely defined.

\section{REFERENCES:}

[1] Štolfa J, Vencovský, J, Pavelka K. Doporučené léčebné postupy pro psoriatickou artritidu. Česká revmatologie 2016; 24(4):142-152

[2] Gossec L, Smolen JS, Ramiro S. et al., European League Against Rheumatism (EULAR) recommendations for the management of psoriatic arthritis with pharmacological therapies 2015 update. Ann Rheum Dis 2015;0:112.

[3] Coates LC, Fransen J, Helliwell PS. Defining minimal disease activity in psoriatic arthritis: a proposed objective target for treatment. Ann Rheum Dis 2010; 69: 48-53.

[4] Schoels M, Aletaha D, Alasti F, et al. Disease activity in psoriatic arthritis (PsA): defining remission and treatment success using the DAPSA score. Ann Rheum Dis 2015.

Acknowledgements: Supported by the Research program of the Ministry of health of Czech Republic: IGA MZ CR: No. 00000023728

Disclosure of Interest: None declared

DOI: 10.1136/annrheumdis-2018-eular.6194

\section{AB0926 EFFECTIVENESS OF CERTOLIZUMAB PEGOL IN PSORIATIC ARTHRITIS. RELATIONSHIP WITH SMOKING STATUS AND BMI}

J. Campos Esteban ${ }^{1}$, A. Conesa Mateos ${ }^{2}$, M. Fernandez-Prada ${ }^{3}$, R. ExpósitoMolinero $^{4}$, P. Rubio Muñoz ${ }^{5}$, J.R. Lamua-Riazuelo ${ }^{6}$, P. Navarro-Alonso ${ }^{7}$, P. Ahijado Guzmán ${ }^{6}$, R. Garcia-Portales ${ }^{8}$, A. Urruticoechea-Arana ${ }^{9}$, C.M. Gonzalez Fernandez ${ }^{10,10}$, on behalf of RENACER Study Group. ${ }^{1}$ Rheumatology, Hospital Universitario Puerta de Hierro, Madrid; ${ }^{2}$ Rheumatology, Hospital Clinico Universitario, Valencia; ${ }^{3}$ Rheumatology, Hospital Universitario de Guadalajara, Guadalajara; ${ }^{4}$ Rheumatology, Hospital Comarcal de Laredo, Laredo; ${ }^{5}$ Rheumatology, Hospital Universitari Germans Trias i Pujol, Badalona; ${ }^{6}$ Rheumatology, Hospital del Henares, Alcala de Henares; ${ }^{7}$ Rheumatology, Hospital de Fuenlabrada, Fuenlabrada; ${ }^{8}$ Rheumatology, Hospital Virgen de la Victoria, Malaga; ${ }^{9}$ Rheumatology, Hospital Can Misses, Ibiza; ${ }^{10}$ Rheumatology, Hospital General Universitario Gregorio Marañón, Madrid, Spain

Background: Previous literature have investigated that tobacco and weight in patients with psoriatic arthritis (PsA) is associated with a poorer response to antiTNF.

Objectives: To investigate the response and survival of Certolizumab pegol (CZP) in PsA patient in daily clinical practice according to their baseline smoking status and Body Mass Index (BMI).

Methods: Multicentric cohort of PsA patients treated with CZP according to routine clinical practice. This study was approved by local Ethics Committee. Maximum observation time was 12 months. Effectiveness variables: DAS28 (CRP). Survival rate: Kapplan-Meier.

Results: 262 patients with PsA were included: $43.5 \%$ male, mean (SD) age 49.9 (11.9) years, mean (Q1-Q3) disease duration 6.9 (1.9-9.3) years, and $14.9 \%$ of patients were HLAB27 positive. Among these, 229 (87.4\%) had known smoking status $(29.7 \%$ smokers and $70.3 \%$ never smokers) and $85(32 \%)$ had known BMI (median $26.9 \mathrm{~kg} / \mathrm{m}^{2}$, SD 4.7). Statistically significant differences in DAS28 were observed at last visit comparing to baseline in both groups according to $\mathrm{BMI}$ and smoking status (table 1 ).

CZP retention rate was $78.5 \%$ in non-smokers and $76.7 \%$ in smokers. In patients with $\mathrm{BMI}<25 \mathrm{~kg} / \mathrm{m}^{2} \mathrm{CZP}$ retention rate was $78.6 \%$ compared to $78.9 \%$ in patients with $\mathrm{BMI} \geq 25 \mathrm{~kg} / \mathrm{m}^{2}$ (figure 1). No statistical differences were observed in both sub-groups.

Abstract AB0926 - Table 1

\begin{tabular}{llc}
\hline & & DAS28 \\
\hline Baseline & $\mathrm{BMl}<25 \mathrm{~kg} / \mathrm{m}^{2}$ & $4.6(0.9)$ \\
& $\mathrm{BMl} \geq 25 \mathrm{~kg} / \mathrm{m}^{2}$ & $4.5(0.8)$ \\
& Never smokers & $4.6(0.9)$ \\
Last visit & Smokers & $4.6(0.9)$ \\
& $\mathrm{BMl}<25 \mathrm{~kg} / \mathrm{m}^{2}$ & $3.6(1.1)^{\star}$ \\
& $\mathrm{BMl} \geq 25 \mathrm{~kg} / \mathrm{m}^{2}$ & $3.9(1.0)^{\star}$ \\
& Never smokers & $3.9(1.0)$ \\
& & $\#$ \\
& Smokers & $3.3(0.8)$ \\
& & $\#$ \\
\hline
\end{tabular}

${ }^{*} \mathrm{p}<0,05$, Wilcoxon test; $\# \mathrm{p}<0.001$ T-Student's test (last visit vs basal).

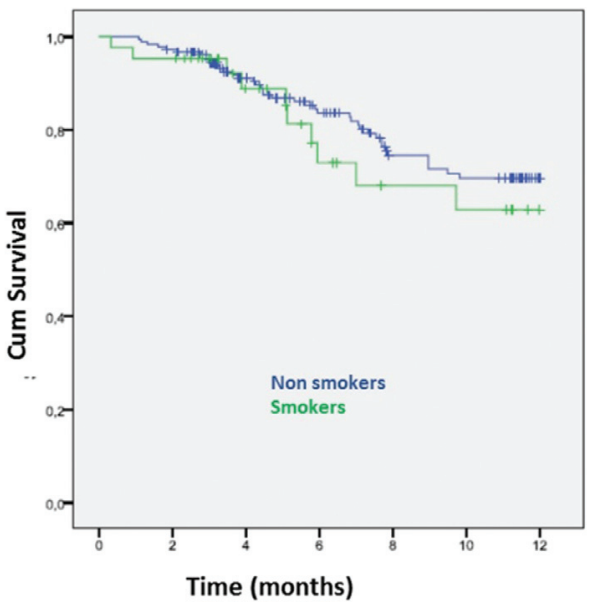

Abstract AB0926 - Figure 1. CZP Retention Rate according to BMI and smoking status in PsA patients.

Conclusions: In this daily clinical practice study of patientes with PsA treated with certolizumab pegol there was a significant decrease in DAS28-CRP independent of smoking status and BMI. No differences were found in the retention rate of certolizumab pegol based on these two variables.

Disclosure of Interest: J. Campos Esteban: None declared, A. Conesa Mateos: None declared, M. Fernandez-Prada: None declared, R. Expósito-Molinero: None declared, P. Rubio Muñoz: None declared, J. R. Lamua-Riazuelo: None declared, P. Navarro-Alonso: None declared, P. Ahijado Guzmán: None declared, R. Garcia-Portales Consultant for: Celgene, Speakers bureau: UCB, Pfizer, Roche, A Urruticoechea-Arana: None declared, C. Gonzalez Fernandez Consultant for: Celgene, MSD, Novartis, Janssen, Speakers bureau: UCB, Abbvie, Pfizer, BMS Roche, Celgene, Janssen DOI: 10.1136/annrheumdis-2018-eular.5983

\section{AB0927 PROBABILITY AND IMPACT OF ACHIEVING LOW DISEASE ACTIVITY OR REMISSION IN PATIENTS WITH PSORIATIC ARTHRITIS TREATED WITH APREMILAST: POOLED ANALYSIS OF THE PALACE 1-3 PHASE 3 TRIALS}

I. McInnes ${ }^{1}$, P.J. Mease ${ }^{2}$, F. Behrens ${ }^{3}$, A.-M. Orbai ${ }^{4}$, M. Brunori ${ }^{5}$, L. Teng $^{5}$, B. Guerette ${ }^{5}$, J. Smolen ${ }^{6} .{ }^{1}$ University of Glasgow, Glasgow, UK; ${ }^{2}$ Swedish Medical Center and University of Washington School of Medicine, Seattle, USA; ${ }^{3}$ Goethe University, Frankfurt, Germany; ${ }^{4}$ Johns Hopkins Arthritis Center and Johns Hopkins University School of Medicine, Baltimore; ${ }^{5}$ Celgene Corporation, Summit, USA; ${ }^{6}$ University of Vienna, Vienna, Austria

Background: Baseline (BL) disease characteristics and short-term response status and its implications for long-term achievement of low disease activity (LDA) or remission $(R E M)$ in pts with active psoriatic arthritis $(P S A)$ treated with apremilast (APR) are unknown. 